\title{
Isolation and Identification of Two Antibacterial Agents from Chromolaena odorata L. Active against Four Diarrheal Strains
}

\author{
Ménonvè Atindehou ${ }^{1,2}$, Latifou Lagnika ${ }^{2}$, Bernard Guérold ${ }^{1}$, Jean Marc Strub ${ }^{3}$, Minjie Zhao ${ }^{4}$, \\ Alain Van Dorsselaer ${ }^{3}$, Eric Marchioni ${ }^{4}$, Gilles Prévost ${ }^{5}$, Youssef Haikel ${ }^{1,6}$, Corinne Taddéi ${ }^{6}$, \\ Ambaliou Sanni ${ }^{2}$, Marie-Hélène Metz-Boutigue ${ }^{1 \#}$ \\ ${ }^{1}$ Inserm UMR 1121, University of Strasbourg, Strasbourg, France \\ ${ }^{2}$ Université d’Abomey-Calavi, Laboratoire de Biochimie et Biologie Moléculaire (LBBM), Cotonou, Bénin \\ ${ }^{3}$ CNRS UMR7178, University of Strasbourg, Strasbourg, France \\ ${ }^{4}$ IPHC-DSA, CNRS, University of Strasbourg, Strasbourg, France \\ ${ }^{5}$ EA 7290, University of Strasbourg, Strasbourg, France \\ ${ }^{6}$ Faculté de Chirurgie Dentaire, Université de Strasbourg, Strasbourg, France \\ Email: *marie-helene.metz@inserm.fr
}

Received January 8, 2013; revised February 9, 2013; accepted March 10, 2013

\begin{abstract}
Chromolaena odorata L (Asteraceae) is a bad invasive plant, found in the humid tropics and sub-tropics worldwide. It is used against dysentery, diarrhea, malaria, wound healing, headache and toothache in traditional medicine. In the present study, we investigated the antibacterial activities of different leaves extracts of Chromolaena odorata L. (cyclohexane, dichloromethane, ethyl acetate and butanol) against four clinical diarrheal strains (Klebsiella oxytoca, Salmonella enterica, Shigella sonnei and Vibrio cholera). We demonstrated that $C$. odorata leaves extracts show an antibacterial activity between 0.156 and $1.25 \mathrm{mg} / \mathrm{mL}$. Bioassay-guided chromatography by bioautography with iodonitrotetrazolium-based colorimetric assay allowed the isolation and identification of two active compounds. After the combination of RP-HPLC, mass spectrometry analysis, 1D and 2D-NMR spectroscopy, we isolated and characterized two active molecules corresponding to 3',4',5,6,7-Pentamethoxyflavone (Sinensetin) and 4',5,6,7-Tetramethoxyflavone (Scutellareintetramethyl ether).
\end{abstract}

Keywords: Chromolaena odorata; 3',4',5,6,7-Pentamethoxyflavone (Sinensetin); 4',5,6,7-Tetramethoxyflavone (Scutellareintetramethyl ether); Antibacterial Activity; Diarrheal Strains

\section{Introduction}

Intestinal infectious diseases are widespread around the world, especially in Africa where they constitute the second cause of mortality in children under five years [1]. Among bacteria responsible for these infections, Salmonella enterica, Shigella sonnei and Vibrio cholera, both Gram-negative, are the most represented [2]. S. enterica and $S$. sonnei are also discovered in the infected intestinal tracts of patients. Non-O1 V. cholerae is associated with sporadic cases of gastroenteritis and extra-intestinal infections whereas Klebsiella oxytoca, over Gram-negative, is held responsible for colitis urinary tract infections, respiratory diseases, post-antibiotic diarrhoea, hemorrhagic colitis [3], recurrent colitis in Crohn's disease [4] and nosocomial infections [5]. Both bacteria strains are

\footnotetext{
*Conflict of interest: The authors have declared that there is no conflict of interest.

${ }^{\#}$ Corresponding author.
}

frequently associated with dysentery. Antibiotics are commonly used for severe intestinal infectious but unfortunately, bacteria are continuously develop resistance to antibiotic. Therefore it appears crucial to discover new antimicrobial agents to overcome the overwhelming drug resistance. A potential approach consists of isolating organic compounds from medicinal plants belonging to traditional pharmacopoeias of the world.

According to the World Health Organization (WHO), $80 \%$ of the African population uses medicinal plants for their primary health needs and $40 \%$ of prescriptions in China are based on medicinal plants [6]. Seventy-five percent of Germans have used complementary or natural remedies [7] and in United States more than 158 million Americans spent $\$ 17$ billion for complementary and alternative therapy products [8].

An ethnopharmacological survey in Benin allows identifying several plants used in traditional medicine for the 
treatment of intestinal infections. Among them, Chromolaena odorata (formerly Eupatorium odoratum) was less studied for antibacterial activities. In Vietnam, fresh leaves or their decoction are used throughout for the treatment of leech bite, soft tissue wounds, burning wounds, skin infection and dentoalveolitis [9]. Furthermore, a study in northern Thailand shows that $C$. odotrata is used in the primary healthcare of postpartum women. Reports from many users of $C$. odorata state effects on indigestion and peptic ulcer wounds, bleeding stoppage, healing acceleration, refreshing [10].

In the present study, we focused on the antibacterial activities of Chromolaena odorata against four bacteria that causes intestinal tract infectious: Klebsiellaoxytoca Salmonella enterica, Shigella sonnei, and Vibrio cholerae. After determination of their minimal inhibitory concentration (MIC) and bioguided isolation, the antibacterial agents from $C$. odorata were characterized by mass spectrometry and NMR analysis.

\section{Materials and Methods}

\subsection{Bacteria Strains}

Four strains (Klebsiellaoxytoca, Salmonella enterica, Shigella sonnei, and Vibrio cholera) were isolated from patients concerned by diarrhea at University hospital (CHRU) of Strasbourg (France) and obtained from the team of Dr. Gilles Prévost. Bacteria are cultivated in Mueller Hinton (MHB, Merck, Darmstadt, Germany).

\subsection{Plant Material}

Chromolaena odorata L. (Asteraceae) is collected during the rainy season in Abomey-Calavi (Benin). The taxonomic identification was obtained from a botanist and a voucher specimen was deposited at the National Herbarium of Abomey-Calavi in Benin (AA6390HNB).

\subsection{Extraction and Isolation}

Leaves were dried in the dark to avoid degradation of the active components and powdered with a blender. An aliquot (50 g) was sequentially extracted under agitation (IKA KS260 Basic, Staufen, Germany) at room temperature $\left(20^{\circ} \mathrm{C}\right)$ with cyclohexane $\left(\mathrm{C}_{6} \mathrm{H}_{12}\right)$, dichloromethane $\left(\mathrm{CH}_{2} \mathrm{Cl}_{2}\right)$, ethyl acetate $\left(\mathrm{C}_{4} \mathrm{H}_{8} \mathrm{O}_{2}\right)$ and butanol $\left(\mathrm{C}_{4} \mathrm{H}_{10} \mathrm{O}\right)$. After the first extraction with $\mathrm{C}_{6} \mathrm{H}_{12}(2 \times 150$ $\mathrm{mL}, 1 \mathrm{~h}$ ), the extract was filtered under vacuum and the filtrate was dried in a rotary evaporator (Stuart RE 300, Staffordshire, UK). The residue of this first extraction was dried under the laminar airflow chamber and used for successive similar extractions with the three others solvents.

Each extract (20 mg) was submitted to liquid chromatography on a Sephadex G-25 column $(0.9 \mathrm{~cm} \times 3.5 \mathrm{~cm}$,
GE Healthcare, Sephadex ${ }^{\text {TM }}$ G-25 Superfine, Uppsala, Sweden) and eluted with three successive solvents: solvent $1\left(\mathrm{CHCl}_{3} / \mathrm{CH}_{3} \mathrm{OH} / \mathrm{H}_{2} \mathrm{O} ; 60: 30: 4.5\right.$; v:v:v), solvent 2 $\left(\mathrm{CHCl}_{3} / \mathrm{CH}_{3} \mathrm{OH} ; 2: 1 ; \mathrm{v}: \mathrm{v}\right)$, solvent $3\left(\mathrm{CHCl}_{3} / \mathrm{CH}_{3} \mathrm{OH} /\right.$ $\mathrm{H}_{2} \mathrm{O}$; 40:35:10; v:v:v). Elution was performed with $5 \mathrm{~mL}$ of solvent $1,2.5 \mathrm{~mL}$ of solvent 2 and $2.5 \mathrm{~mL}$ of solvent 3 . Each eluted fraction was dried under a stream of nitrogen using N-EVAP model 111 (Organomation Assoc. INC, Berlin South, USA).

\subsection{Monodimensional and Bidimensionalthin-Layer Chromatography}

Dried fractions were solubilized with solvent 2 (30 - 50 $\mu \mathrm{l})$ and loaded on glass plates, Kieselgel 60 F254 HPTLC $(10 \mathrm{~cm} \times 10 \mathrm{~cm})$ or TLC $(20 \mathrm{~cm} \times 20 \mathrm{~cm})$ (Merck, Darmstadt, Germany). The silica plates were developed in a pre-saturated vertical twin-through glass chamber $25 \mathrm{~cm} \times 25 \mathrm{~cm} \times 10 \mathrm{~cm}$ (Camag, Muttenz, Switzerland) containing $35 \mathrm{~mL}$ of solvent $4\left(\left(\mathrm{C}_{2} \mathrm{H}_{5}\right)_{2} \mathrm{O} /\right.$ $\mathrm{CH}_{3} \mathrm{OH} / \mathrm{CH}_{3} \mathrm{COOH}$; 90:1:2; v:v:v) for monodimensional TLC. A two-dimensional thin-layer chromatography was performed for a better separation of different compounds present. For bidimensional TLC, plates were developed in solvent $5\left(\mathrm{CHCl}_{3} /\left(\mathrm{CH}_{3}\right)_{2} \mathrm{CO}\right.$; $95: 5$; v:v) for the first dimension, dried and placed in solvent $4\left(\mathrm{C}_{2} \mathrm{H}_{5}\right)_{2} \mathrm{O} /$ $\mathrm{CH}_{3} \mathrm{OH} / \mathrm{CH}_{3} \mathrm{COOH}$; 90:1:2; v:v:v) for the second dimension. Compounds were detected under UV light (365 $\mathrm{nm})$.

\subsection{Antibacterial Assay}

Antibacterial activity of plants extracts was determined by using a microdilution bioassay. Bacteria were cultured aerobically at $37^{\circ} \mathrm{C}$ in a Mueller Hinton Broth (MHB, Merck, Darmstadt, Germany) with shaking at 300 rpm for $18 \mathrm{~h}$ in an incubator (Tritamax 1000, Heidolph, Germany). The following bacteria strains were tested: Klebsiella oxytoca, Salmonella enterica, Shigella sonnei, and Vibrio cholera. Bacterial activity was tested by measuring the inhibition of bacterial growth [11]. Extracts (20 $\mathrm{mg}$ ) were suspended in acetone/water $(10: 90 \mathrm{v}: \mathrm{v}, 1 \mathrm{~mL})$ and diluted to a concentration of 10, 5, 2.5, 1.25, 0.625, $0.312,0.156 \mathrm{mg} / \mathrm{mL}$ in MHB. The samples $(100 \mu \mathrm{L})$ were incubated in 96 wells microplates with $100 \mu \mathrm{L}$ of a midlogarithmic phase culture of bacteria with a starting absorbance of 0.001 at $620 \mathrm{~nm}$. Each assay was performed in triplicate. Cefotaxime (Sigma Aldrich ChemieGmbh, Steinheim, Germany) was used as positive control. Bacterial growth in the absence of antibacterial agents is used for control and acetone/water (10:90; v:v) was also tested. After $18 \mathrm{~h}$ of incubation under agitation at $37^{\circ} \mathrm{C}$, the Minimal Inhibitory Concentration (MIC) was determined by addition of $40 \mu \mathrm{L}$ of Iodonitrotetrazolium chloride (INT, Sigma Aldrich Chemie GmbH, Stein- 
heim, Germany) [12,13] at $0.2 \mathrm{mg} / \mathrm{mL}$ and the plates were incubated for $1 \mathrm{~h}$ at $37^{\circ} \mathrm{C}$ [13]. Bacterial growth was assessed by a reddish-pink color and the MIC was determined as the lowest concentration of plant extract for which the color does not turn red after the addition of INT.

\subsection{Isolation of the Active Components Present in Plant Extracts by Bioautography}

Isolation of the active components was obtained by using the bioautography procedure [12,13]. A culture of Salmonella enterica in MHB with $0.7 \%$ agar (Gibco, Paisley, Scotland) with absorbance of 0.01 at $620 \mathrm{~nm}$ was sprayed on HPTLC plates. Plates were incubated for $18 \mathrm{~h}$ at $37^{\circ} \mathrm{C}$ and $100 \%$ relative humidity. The detection of antibacterial spot was obtained after spraying of plates with an aqueous solution of INT (1 $\mathrm{mg} / \mathrm{mL})$ and incubation for $1 \mathrm{~h}$. Inhibition of bacterial growth was indicated by clear zones on the bidimensional plates. The inhibition zones were scraped on TLC plates similarly prepared. This material was used for a liquid column chromatography $(1 \mathrm{~cm} \times 0.2 \mathrm{~cm})$ and the active compounds were eluted with methanol, dried by $\mathrm{N}$-Evap, suspended in a mixture of isopropanol/ $\mathrm{H}_{2} \mathrm{O} /$ trifluoroacetic acid (TFA) (30:69.9:0.1; v:v:v) and centrifuged at RT 15.000 rpm for $15 \mathrm{~min}$.

\subsection{RP-HPLC}

In order to purify the active components, the supernatants were analyzed by HPLC using a DIONEX Ultimate 3000 system and a Vydac C18 218TP510 Grace column (particle size 3 - $20 \mu \mathrm{m}$ and pore diameter $300 \AA$ Davidson, USA). The elution was obtained at RT with a gradient (as indicated on the chromatogram) of Solvent A: Isopropanol/ $\mathrm{H}_{2} \mathrm{O} / \mathrm{TFA}$ (30:69.9:0.1; v:v:v) and Solvent B: Isopropanol/ $\mathrm{H}_{2} \mathrm{O} / \mathrm{TFA}(90: 9.91: 0.09 ; \mathrm{v}: \mathrm{v}: \mathrm{v})$ at a flow rate 1.5 $\mathrm{mL} / \mathrm{min}$. The detection was obtained at $254 \mathrm{~nm}$.

\subsection{MALDI-MS Analysis (MALDI-TOF/TOF Ultraflex $^{\mathrm{TM}}$ )}

Mass measurements were performed using MALDI-TOF (Ultraflex $^{\mathrm{TM}}$ MALDI-TOF/TOF, BrukerDaltonics, Bremen, Germany). This instrument was used with a positive reflectron and a maximum accelerating potential of $25 \mathrm{kV}$ applied to the target and $26 \mathrm{kV}$ applied to the reflectron. The value of the delayed extraction was optimized to 110 ns in order to obtain the best resolution of the peptides used for calibration. The laser used was a nitrogen laser $(337 \mathrm{~nm})$ operating at a frequency of 20 $\mathrm{Hz}$. Data acquisition was performed in a mass range from $100 \mathrm{~m} / \mathrm{z}$ to $500 \mathrm{~m} / \mathrm{z}$.

Extracts $(0.5 \mu \mathrm{L})$ were mixed with matrix $(0.5 \mu \mathrm{L})$ loaded on the target and dried at atmospheric pressure us- ing the dried droplet method. In order to increase the sensivity of the technique, two matrices were used: $\alpha$-cyano-4-hydroxy-cinnamic (CHCA) (BrukerDaltonics. Coventry, UK) and 2,5-dihydrobenzoic acid (DHB) (Sigma Aldrich, Steinheim, Germany). A saturated solution of CHCA matrix in $\mathrm{H}_{2} \mathrm{O} / \mathrm{ACN}, 1: 1$ was diluted three times with $\mathrm{H}_{2} \mathrm{O} / \mathrm{ACN}$ 50:50 acidified with 0.1\% TFA. DHB matrix was prepared at a concentration of $10 \mathrm{mg} / \mathrm{mL}$ in $\mathrm{H}_{2} \mathrm{O}$ / ACN, 1:1.

\subsection{Gas Chromatography-Electron Impact MS}

MS analyses were performed using an Agilent Technologies 78901A (Santa Clara, CA, USA) gas chromatograph equipped with a split/splitless programmed temperature injector and an Agilent J\&W DB5MS fused silica column ( $30 \mathrm{~m}$ by $0.25 \mathrm{~mm}$; film thickness, $0.25 \mu \mathrm{m}$ ) connected to a JEOLAccut of JMS-T100GCV spectrometer (ChemSW, Inc., Fairfield, CA, USA). The mass spectrometer was operated in electron impact mode at $70 \mathrm{eV}$, and spectra were recovered over a mass range from $\mathrm{m} / \mathrm{z}$ 35 to 700 with a cycle time of 0.4 scans/s. The oven temperature was programmed to increase from $80^{\circ} \mathrm{C}$ to $300^{\circ} \mathrm{C}$ at a rate of $10^{\circ} \mathrm{C} / \mathrm{min}$, and then kept isothermal for $8 \mathrm{~min}$. The other conditions were as follows: helium split, 1:10; constant flow rate, $1 \mathrm{~mL} / \mathrm{min}$; transfer line temperature, $280^{\circ} \mathrm{C}$ and $\mathrm{MS}$ source temperature, $250^{\circ} \mathrm{C}$. Samples were injected with an auto-injector at $280^{\circ} \mathrm{C}$ using the split mode with a ratio of 1:5.

\subsection{Spectroscopy NMR}

The two isolated compounds were dissolved in $\mathrm{CDCl}_{3}$ and analyzed using a BRUKER Avance III $500 \mathrm{MHz}$ spectrometer equipped with CapNMR ${ }^{\mathrm{TM}}$ Protasis $5 \mu \mathrm{L}$ Probe Head (Savoy, IL, USA).

\section{Results}

\subsection{Antibacterial Activity}

Chromolaenaodorata selection was based on an ethnopharmacological survey conducted among traditional healers of Benin. 14 plants were selected and tested in a preliminary study and $C$. odorata was selected as one of the most active plant. C. odorata leaves extracts were prepared and antibacterial activity extracts was determined by using iodonitrotetrazolium salt. Results demonstrate that $C$. odorata display an antibacterial activity ranging from 0.156 to $1.25 \mathrm{mg} / \mathrm{mL}$ against Klebsiellaoxytoca, Salmonella enterica, Shigella sonnei and Vibrio cholerae (Table 1). The best activity was obtained against $V$. cholerae with a MIC of $0.156 \mathrm{mg} / \mathrm{mL}$ for the dichloromethane extract and a MIC of $0.312 \mathrm{mg} / \mathrm{mL}$ for the butanol extract. 


\subsection{Separation of Organic Compounds and Bioguided Isolation of Active Molecules}

After purification of the extracts on a Sephadex G-25, TLC was performed (Figure 1). $\mathrm{CH}_{2} \mathrm{Cl}_{2}$ and $\mathrm{C}_{4} \mathrm{H}_{8} \mathrm{O}$ extracts display a high pattern of similarity. In order to improve the separation of the components, we performed a two-dimensional chromatography (Figure 2) combined to a bioautography against Salmonella. We were therefore able to detect two major inhibition zones (Cp 1, Cp2; Figure 2(a)) of bacterial growth for $\mathrm{C}_{6} \mathrm{H}_{12}, \mathrm{CH}_{2} \mathrm{Cl}_{2}$ and $\mathrm{C}_{4} \mathrm{H}_{8} \mathrm{O}$ leaves extracts. These three extracts were pooled for the isolation of molecules.

The inhibition zones named Cp 1 and Cp 2 (Figure 2(a)) were recovered and isolated by RP-HPLC showing major peaks at $12 \mathrm{~min}$ and 24 min respectively (Figure 2(b)).

\subsection{Characterization of Active Molecules}

The molecular formula of $\mathrm{Cp} 1$ and $\mathrm{Cp} 2$ was determined as $\mathrm{C}_{20} \mathrm{H}_{20} \mathrm{O}_{7}$ at $\mathrm{m} / \mathrm{z} 372$ and $\mathrm{C}_{19} \mathrm{H}_{18} \mathrm{O}_{6}$ at $\mathrm{m} / \mathrm{z} 342$

Table 1. Antimicrobial activity (MIC in $\mathrm{mg} / \mathrm{mL}$ ) of Chromolaena odorata leave extracts.

\begin{tabular}{ccccc}
\hline \multicolumn{5}{c}{ Minimal inhibitory concentration (mg/ml) } \\
\hline $\begin{array}{c}\text { Microorganisms } \\
\text { Cyclohexane } \\
\text { extract }\end{array}$ & $\begin{array}{c}\text { Dichloromethane } \\
\text { extract }\end{array}$ & $\begin{array}{c}\text { Ethyl acetate } \\
\text { extract }\end{array}$ & $\begin{array}{c}\text { Butanol } \\
\text { extract }\end{array}$ \\
\hline $\begin{array}{c}\text { Klebsiella } \\
\text { oxytoca }\end{array}$ & 1.25 & 0.625 & 0.625 & 1.25 \\
$\begin{array}{c}\text { Salmonella } \\
\text { enterica }\end{array}$ & 1.25 & 0.625 & 0.625 & 0.625 \\
$\begin{array}{c}\text { Shigella sonnei } \\
\text { Vibrio cholerae }\end{array}$ & 1.25 & 0.625 & 0.625 & 0.625 \\
\hline
\end{tabular}

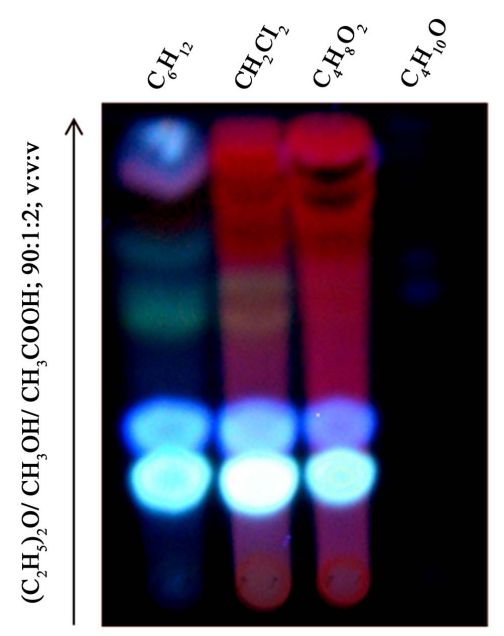

Figure 1. Detection at $365 \mathrm{~nm}$ of thin layer chromatography of Chromolaena odorata extracts (cyclohexane $\mathrm{C}_{6} \mathrm{H}_{6}$, dichloromethane $\mathrm{CH}_{2} \mathrm{Cl}_{2}$, ethyl acetate $\mathrm{C}_{4} \mathrm{H}_{8} \mathrm{O}_{2}$ and butanol $\mathrm{C}_{4} \mathrm{H}_{10} \mathrm{O}$ ) in $\left(\mathrm{C}_{2} \mathrm{H}_{5}\right)_{2} \mathrm{O} / \mathrm{CH}_{3} \mathrm{OH} / \mathrm{CH}_{3} \mathrm{COOH} ; 90: 1: 2$; v:v:v.

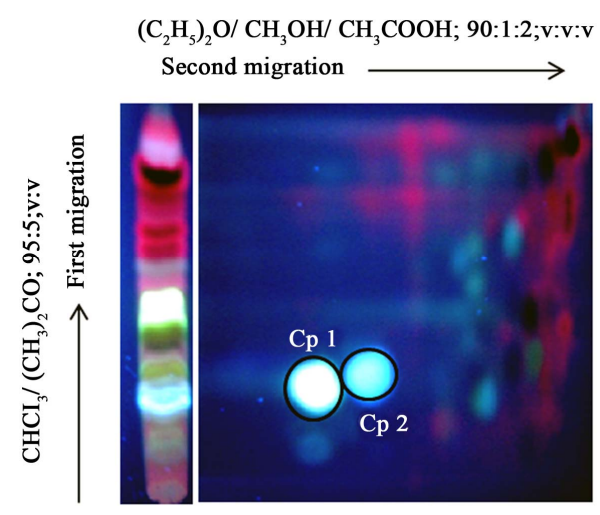

(a)
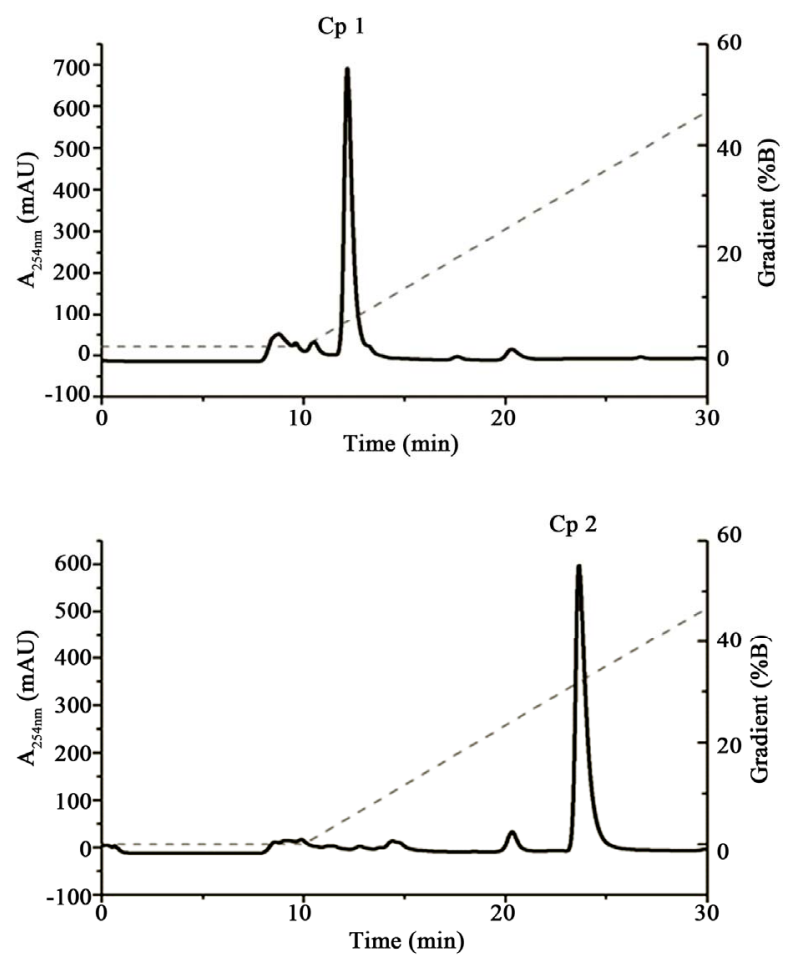

(b)

Figure 2. Isolation of antibacterial agents. (a) Bidimensional migration of Chromolaena odorata extracts. Bioautography test against Salmonella enterica shows two inhibition zones of bacterial growth named Compound 1 (Cp 1) and Compound 2 ( $\mathrm{Cp} 2)$ according to procedure described in Materials and Methods section. (b) HPLC purification of $\mathrm{Cp} 1$ and $C p$ 2. Cp 1 and $C p 2$ were isolated by HPLC using DIONEX Ultimate 3000 System and column Vydac C18 218TP510 (particle size 3 - $20 \mu \mathrm{m}$, pore diameter is $300 \AA$ ). Elution at RT was obtained with Solvent A (Isopropanol $30 \%, \mathrm{H}_{2} \mathrm{O} 69.9 \%$, TFA $0.1 \%$,) and Solvent B (Isopropanol $90 \%, \mathrm{H}_{2} \mathrm{O} 9.91 \%$, TFA $0.09 \%$ ) with the gradient indicated by dashed line and a flow rate of $1.5 \mathrm{~mL} / \mathrm{min}$.

respectively. Structural determination of the compounds by NMR enabled us to identify two flavonoids. The complete assignments of ${ }^{1} \mathrm{H}$ and ${ }^{13} \mathrm{C}$ NMR spectra were achieved with the help of COSY, NOESY and HSQC. 
Compound 1: d 7.49 (1H, dd, $\left.\mathrm{J}=17, \mathrm{~J}=4 \mathrm{H}_{\mathrm{Z}}, \mathrm{Hc}\right)$, 7.31 (1H, d, J = $\left.4 \mathrm{H}_{\mathrm{Z}}, \mathrm{He}\right), 6.95\left(1 \mathrm{H}, \mathrm{d}, \mathrm{J}=17 \mathrm{H}_{\mathrm{Z}}, \mathrm{Hd}\right)$, 6.78 (1H, s, Ha), 6.60 (1H, s, Hb), 3.97 (6H, s, 7-OCH3, 5-ОСН3), 3.96 (3Н, s, 3'-ОСН3), 3.94 (3Н, s, 4'-ОСН3), 3.90 (3H, s, 6-OCH3).

Compound 2: d 7.82 (2H, d, J = $\left.18 \mathrm{H}_{\mathrm{Z}}, \mathrm{Hc}\right), 7.00$ (2H, d, J = $\left.18 \mathrm{H}_{\mathrm{Z}}, \mathrm{Hd}\right), 6.79$ (1H, s, Ha), 6.68 (1H, s, Hb), 3.97 (6H, s, 7-OCH3, 5-OCH3), 3.90 (3H, s, 6-OCH3), 3.87 (3H, s, 4'-OCH3).

Cp 1 has been identified as 3',4',5,6,7-Pentamethoxyflavone or Sinensetin and Cp 2 as 4',5,6,7-Tetramethoxyflavone or Scutellareintetramethyl ether (Figure 3).

The synthetic molecules corresponding to our natural isolated compounds were purchased from Extrasynthese (Genay, France) and their NMR spectra were compared showing similar profiles between the two series of analysis.

\section{Discussion}

Recent data demonstrated that the bacteria used in this study were resistant to antibiotics. In 2011, Younes re-

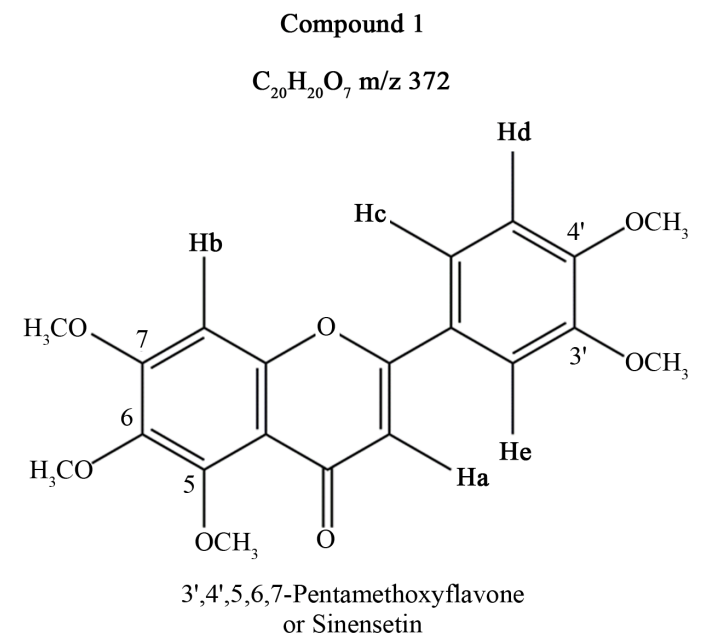

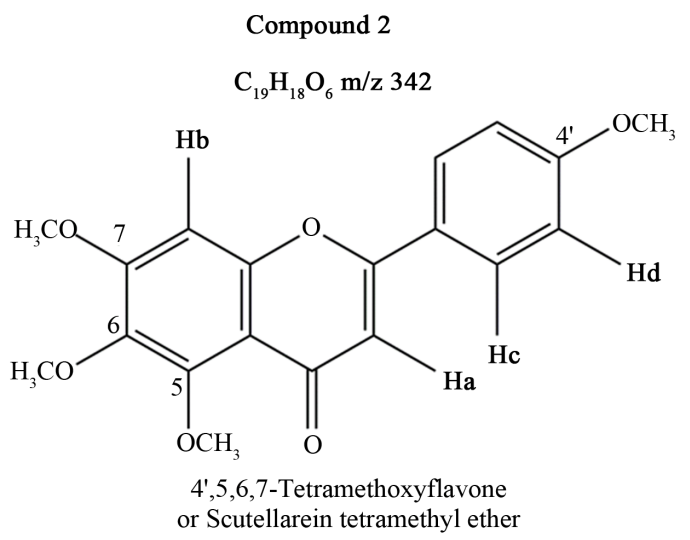

Figure 3. Structural identification of Compounds 1 and 2. ported that $K$. oxytoca isolated from Scottish patients display a resistance to cefotaxime and ceftazidime. This resistance is due to the expression of cefotaximase by the bacteria [14]. Furthermore, during the last decade resistance of Salmonella for ciprofloxacin was reported in the United States [15]. Several strains of Shigella also display antibiotic resistance to tetracycline and trimetropine-sulfamethoxazole. Another study in the Zhejiang province (China) highlighted the resistance of Shigella to multiple antibiotics, such as aztreonam (30.8\%), ampicillin (92.3\%), piperacillin (61.5\%), ceftazidime (30.8\%), cefotaxime $(30.8 \%)$, and gentamicin $(53.8 \%)$. V. cholerae is also able to develop multiple drug resistances against antibiotics as reported in 2010 [16]. All these examples strongly argue to find new active agents. For this, screening of the antibacterial activities of medicinal plants constitute a promising route towards the discovery of new antimicrobial compounds.

Some studies demonstrated that $C$. odorata leaves extracts display antibacterial activities against Pseudomonas aeruginosa, Streptococcus faecalis [17], Neisseria gonorrhoeae [18] and antifungal activities against Cryptococcus neoformans, Microsporumgypseum, Trichophytonmentagrophytes and Trichophytonrubrum [19]. In addition, methanol/dichloromethane (1:1) extraction of C. Odorata's roots, showed a significant antibacterial activity against Escherichia coli and Salmonella typhi [20]. C. odorata also displays antiinflammatory activities [21] and contributes to wound healing [22], hemostasis and blood coagulation, antioxidant activity [23] as well as cytotoxic effects against cancerous cells [24-27].

The two compounds identified in this study belong to the flavonoid family. Flavonoids are polyphenolic compounds mostly present in vegetables. Some flavonoids isolated from medicinal plants show important biological activities such as antiallergic, antiinflammatory, antiviral, anticancer, antioxidant. Interestingly flavonoids exert anti-inflammatory activities in bowel inflammation disease [28]. The two flavonoids identified in this study, sinensetin and scutellareintetramethyl ether have already been identified in a chemical study [29]. In addition, other studies shown that these molecules are quoted as having anticancer, antioxidant properties and in preventing obesity [30]. For the first time, our study demonstrated that Chromolaena odorata antibacterial properties are associated with sinensetin and scutellaréinetetrametyl ether. Some data suggest that composition of medicinal plants varies along the seasons and many others factors [31,32]. Thus, the two flavonoids isolated from $C$. odorata might be used as markers of the antibacterial properties of this plant.

To conclude, this study describes for the first time antibacterial activity of $C$. odorata against four diarrheagenic pathogens strains and validates somehow tradi- 
tional use of this plant in the treatment of intestinal infectious diseases. Bioguided isolation by chemical and biological methods allowed us to characterize two flavonoids, sinensetin and scutellareintetramethyl ether as responsible for these antibacterial activities of Chromolaena odorata.

\section{Acknowledgements}

We are grateful to the Embassy of France in Benin, the Benin government (ARHES project) and the Faculty of Odontology of the University of Strasbourg for their financial supports (M.A.). We thank Drs Céline Marban and Loïc Jerry for critical reading of the manuscript.

\section{REFERENCES}

[1] World Health Organization (WHO), “La Diarrhea,” 2009. http://www.whoint/mediacentre/factsheets/fs330/fr/index html.

[2] Institut de la Francophonie Pour la Médecine Tropicale (IFMT), “Maladies Diarrhéïques: Vue D’ensemble,” 2005. http://www.ifmtauforg/IMG/pdf/maladies-diarrheiques-2 pdf

[3] K. M. Hoffmann, A. Deutschmann, C. Weitzer, M. Joainig, E. Zechner, C. Hogenauer and A. C. Hauer, “Antibiotic-Associated Hemorrhagic Colitis Caused by Cyto-Toxin-Producing Klebsiellaoxytoca," Pediatrics, Vol. 125, No. 4, 2010, pp. e960-e963.

http://pediatrics.aappublications.org/content/125/4/e960 doi:10.1542/peds.2009-1751

[4] A. Plessier, J. Cosnes, J. P. Gendre and L. Beaugerie, "Inter-Current Klebsiellaoxytoca Colitis in a Patient with Crohn's Disease," Gastroenterologie Clinique et Biologique, Vol. 26, No. 8-9, 2002, pp. 799-800.

[5] G. Gorkiewicz, "Nosocomial and Antibiotic-Associated Diarrhoea Caused by Organisms Other than Clostridium difficile," International Journal of Antimicrobial Agents, Vol. 33, No. S1, 2009, pp. S37-S41.

[6] World Health Organization (WHO), "Guidelines on Safety Monitoring of Herbal Medicines in Pharmacovigilance Systems,” 2004.

[7] A. Tuffs, "Three out of Four Germans Have Used Complementary or Natural Remedies,” British Medical Journal, Vol. 325, No. 7371, 2002, p. 990.

http://www.bmj.com/content/325/7371/990.6

doi:10.1136/bmj.325.7371.990/e

[8] C. Marwick, "US Report Calls for Tighter Controls on Complementary Medicine,” British Medical Journal, Vol. 324, No. 7342, 2002, p. 870.

http://www.bmj.com/content/324/7342/870.2

doi:10.1136/bmj.324.7342.870/a

[9] O. Sharma, R. Dawra, N. Kurade and P. Sharma, “A Review of the Toxicosis and Biological Properties of the Genus Eupatorium,” Natural Toxins, Vol. 6, No. 1, 1998, pp. 1-14.

[10] K. Panyaphu, T. V. On, P. Sirisa-Ard, P. Srisa-Nga, S.
Chansa Kaow and S. Nathakarnkitkul, "Medicinal Plants of the Mien (Yao) in Northern Thailand and Their Potential Value in the Primary Healthcare of Postpartum Women,” Journal of Ethnopharmacoly, Vol. 135, No. 2, 2011, pp. 226-237.

[11] Clinical and Laboratory Standards Institute, "Methods for Dilution Antimicrobial Susceptibility Tests for Bacteria That Grow Aerobically; Approved Standard-Seventh Edition," Clinical and Laboratory Standards Institute, Vol. 26, No. 2, 2006, pp. 1-64.

[12] W. J. Begue and R. M. Kline, "The Use of Tetrazolium Salts in Bioautographic Procedure,” Journal of Chromatography, Vol. 64, No. 1, 1972, pp. 182-184.

[13] J. N. Eloff, “A Sensitive and Quick Microplate Method to Determine the Minimal Inhibitory Concentration of Plant Extracts for Bacteria,” Planta Medica, Vol. 64, No. 8, 1998, pp. 711-713.

https://www.thieme-connect.de/DOI/DOI?10.1055/s-200 6-957563 doi:10.1055/s-2006-957563

[14] A. Younes, A. Hamouda and S. G. Amyes, "First Report of a Novel Extended-Spectrum Beta-Lactamase KOXY-2 Producing Klebsiella oxytoca That Hydrolyses Cefotaxime and Ceftazidime,” Journal of Chemotherapy, Vol. 23, No. 3, 2011, pp. 127-130.

[15] F. Medalla, M. Sjolund-Karlsson, S. Shin, E. Harvey, K. Joyce, L. Theobald, B. N. Nygren, G. Pecic, K. Gay, J. Austin, A. Stuart, E. Blanton, E. D. Mintz, J. M. Whichard and E. J. Barzilay, "Ciprofloxacin-Resistant Salmonella enterica Serotype Typhi, United States, 1999-2008,” Emerging Infectious Diseases, Vol. 17, No. 6, 2011, pp. 1095-1098.

http://wwwnc.cdc.gov/eid/article/17/6/10-0594_article.htm doi:10.3201/eid1706.100594

[16] H. L. Alaoui, K. Oufdou and N. E. Mezrioui, "Determination of Several Potential Virulence Factors in Non-o1 Vibrio cholerae, Pseudomonas aeruginosa, Faecal Coliforms and Streptococci Isolated from Marrakesh GroundWater," Water Science and Technology, Vol. 61, No. 7, 2010, pp. 1895-1905.

http://www.iwaponline.com/wst/06107/wst061071895.htm doi:10.2166/wst.2010.263

[17] O. Irobi, “Activities of Chromolaenaodorata (Compositae) Leaf Extract against Pseudomonas aeruginosa and Streptococcus faecalis,” Journal of Ethnopharmacology, Vol. 37, No. 1, 1992, pp. 81-83.

[18] A. Cáceres, H. Menéndez, E. Méndez, E. Cohobón, B. Samayoa, E. Jauregui, E. Peralta and G. Carrillo, "Antigonorrhoeal Activity of Plants Used in Guatemala for the Treatment of Sexually Transmitted Diseases,” Journal of Ethnopharmacology, Vol. 48, No. 2, 1995, pp. 85-88. http://www.sciencedirect.com/science/article/pii/0378874 195012880 doi:10.1016/0378-8741(95)01288-O

[19] A. NgonoNgane, R. EbelleEtame, F. Ndifor, L. Biyiti, P. H. AmvamZollo and P. Bouchet, "Antifungal Activity of Chromolaena odorata (L.) King \& Robinson (Asteraceae) of Cameroon,” Chemotherapy, Vol. 52, No. 2, 2006, pp. 103-106. 
[20] P. Wafo, R. S. Kamdem, Z. Ali, S. Anjum, A. Begum, O. O. Oluyemisi, S. N. Khan, B. T. Ngadjui, X. F. Etoa and M. I. Choudhary, "Kaurane-Type Diterpenoids from Chromoleanaodorata, Their X-Ray Diffraction Studies and Potent Alpha-Glucosidase Inhibition of 16-Kauren-19Oic Acid,” Fitoterapia, Vol. 82, No. 4, 2011, pp. 642-646. http://www.sciencedirect.com/science/article/pii/S036732 6X11000645 doi:10.1016/j.fitote.2011.02.003

[21] V. B. Owoyele, J. O. Adediji and A. O. Soladoye, “Anti-Inflammatory Activity of Aqueous Leaf Extract of Chromolaenaodorata,” Inflammopharmacology, Vol. 13, No. 5-6, 2005, pp. 479-484. doi:10.1163/156856005774649386

[22] T. P. Thang, A. H. Margaret, W. C. George, T. T. Le and H. M. Pham, "An Aqueous Extract of the Leaves of Chromolaena odorata (Formerly Eupatorium odoratum) (Eupolin) Inhibits Hydrated Collagen Lattice Contraction by Normal Human Dermal Fibroblasts," The Journal of Alternative and Complementary Medicine, Vol. 2, No. 3, 1996, pp. 335-343.

[23] K. SrinivasaRao, P. K. Chaudhury and A. Pradhan, "Evaluation of Anti-Oxidant Activities and Total Phenolic Content of Chromolaena odorata," Food and Chemical Toxicology, Vol. 48, No. 2, 2009, pp. 729-732.

[24] A. Suksamrarn, A. Chotipong, T. Suavansri, S. Boongird, P. Timsuksai, S. Vimuttipong and A. Chuaynugul, "Antimycobacterial Activity and Cytotoxicity of Flavonoids from the Flowers of Chromolaena odorata," Archives of Pharmacal Research, Vol. 27, No. 5, 2004, pp. 507-511. http://link.springer.com/article/10.1007\%2FBF02980123 doi:10.1007/BF02980123

[25] T. M. Hung, T. D. Cuong, N. H. Dang, S. Zhu, P. Q. Long, K. Komatsu and B. S. Min, "Flavonoid Glycosides from Chromolaena odorata Leaves and Their in Vitro Cytotoxic Activity,” Chemical and Pharmaceutical Bulletin (Tokyo), Vol. 59, No. 1, 2011, pp. 129-131. https://www.jstage.jst.go.jp/article/cpb/59/1/59_1_129/_a rticle doi:10.1248/cpb.59.129

[26] P. B. Kouame, C. Jacques, G. Bedi, V. Silvestre, D. Loquet, S. Barille-Nion, R. J. Robins and I. Tea, "Phytochemicals Isolated from Leaves of Chromolaena odorata: Impact on Viability and Clonogenicity of Cancer Cell Lines,” Phytotherapy Research, 2012.

[27] P. Taylor, M. Arsenak, M. J. Abad, A. Fernandez, B. Milano, R. Gonto, M. C. Ruiz, S. Fraile, S. Taylor, O. Estrada and F. Michelangeli, "Screening of Venezuelan Medicinal Plant Extracts for Cytostatic and Cytotoxic Activity against Tumor Cell Lines,” Phytotherapy Research, 2012.

[28] R. Gonzalez, I. Ballester, R. Lopez-Posadas, M. D. Suarez, A. Zarzuelo, O. Martinez-Augustin and F. Sanchez de Medina, "Effects of Flavonoids and Other Polyphenols on Inflammation," Critical Reviews in Food Science and Nutrition, Vol. 51, No. 4, 2011, pp. 331-362. doi:10.1080/10408390903584094

[29] R. N. Barua, R. P. Sharma, G. Thyagarajan and W. Hertz, "Flavonoids of Chromolaenaodorata," Phytochemistry, Vol. 17, No. 10, 1978, pp. 1807-1808.

[30] S. I. Kang, H. S. Shin, H. C. Ko and S. J. Kim, "Effects of Sinensetin on Lipid Metabolism in Mature 3T3-L1 Adipocytes,” Phytotherapy Research, Vol. 27, No. 1, 2013, pp. 131-134.

[31] A. Barra, "Factors Affecting Chemical Variability of Essential Oils: A Review of Recent Developments," Natural Product Communications, Vol. 4, No. 8, 2009, pp. 11471154.

[32] R. Bruni and G. Sacchetti, "Factors Affecting Polyphenol Biosynthesis in Wild and FIELD GROWN St. John's Wort (Hypericumperforatum L. Hypericaceae/Guttiferae)," Molecules, Vol. 14, No. 2, 2009, pp. 682-725. 